\title{
OLIVE SPRAY THINNING GUIDELINES
}

\author{
G. Steven Sibbett, University of California Cooperative Extension Farm Advisor, Tulare County \\ William Krueger, University of California Cooperative Extension Farm Advisor, Glenn County
}

\section{WHY THIN YOUR OLIVE CROP?}

Larger fruit. Overloaded trees bear small, unprofitable fruit. If you thin the crop (remove excess olives) during the fruit's early growing period, the remaining fruit will grow larger. The larger fruit command a higher price that more than offsets any reduction in total yield. By thinning the crop, you will bring otherwise substandard-sized olives up to canning sizes.

Higher-quality fruit. Olives harvested from spraythinned trees have a greater flesh-to-pit ratio and a higher oil content than do fruit from untreated trees.

More consistent yearly crops. After a modest crop, shoot growth and prospects for a satisfactory crop the following year are good. In contrast, a heavy crop of olives is followed almost invariably by a light crop.

Early maturity. A moderate crop matures earlier than a heavy crop. An early crop is more likely to get a good reception from the handler, has less competition for harvest labor, is less likely to fall victim to cold weather in the early fall, and ensures a good bloom for the next year.

Lower harvest costs. Olive picking costs are figured on a per-ton basis, so the per-acre harvest costs for a moderate crop are less than for a large crop.

\section{SPRAY THINNING WITH NAA}

The plant growth regulator naphthaleneacetic acid (NAA) absorbs into the leaves and fruit of the olive tree and is then translocated to the fruit stems. An abscission layer forms during the first two weeks after NAA application, causing some fruit to drop.

\section{NAA Formulation for Olive Thinning}

NAA is manufactured in the form of an ammonium salt for commercial use on olive orchards, with 200 grams of active ingredient per gallon. This formulation is marketed as Liqui-Stik Concentrate (EPA reg \#34704-382) by Platte Chemical Company. NOTE: This material does not contain wetting agents.

\section{When to Apply NAA}

Timing is critical. You can use either of two methods to determine the proper time for NAA application.
Full bloom date method. To use the full bloom date method, you must establish the date of full bloom for your orchard. For our purposes, full bloom is the point at which 80 percent of the olive flowers are open (10 percent of the flowers are not yet open and 10 percent of the flowers are dropping petals), petals are white (not brown), and pollen is shedding. To see whether pollen is shedding, you can run your hand down the full length of a blooming shoot. Yellow pollen in your hand indicates shedding. Record the date of full bloom, and apply NAA 12 to 18 days after that date.

Fruit size method. If you base your spray timing on fruit size, spray the trees when young fruit are $1 / 8$ to $3 / 16$ inch in diameter. Figured this way, the time of application varies from 12 to 18 days after full bloom, depending on weather. Most growers and advisors favor using a combination of the full bloom date and fruit size methods to determine the proper time for application.

NOTE: Once again, timing is critical. EPA registration for NAA covers the period from full bloom to $2^{1 / 2}$ weeks after bloom. NAA applications after that point are both illegal and useless. Too early an application will overthin the orchard. Too late an application will yield unsatisfactory results. An application during bloom will destroy the crop.

\section{What Concentration to Use}

The concentration of NAA you use will depend on how you determine spray timing and whether or not you use a spray oil.

Full bloom date method. If you time your spray according to the full bloom date, apply NAA as a dilute spray (300 to 500 gallons per acre [gpa] [approximately 2800 to 4700 liters/hectare]) 12 to 18 days after full bloom. If applied at 10 days, use a concentration of 100 parts per million (ppm). Thereafter, increase the concentration by $10 \mathrm{ppm}$ for each day that treatment is delayed. For example, if you spray 15 days after full bloom, use a concentration of $150 \mathrm{ppm}$.

CAUTION: Abnormally cool weather will delay fruit growth. In such a circumstance, use the fruit size method for spray timing.

Fruit size method. If you use the fruit size method and spray without a spray oil, apply a concentration of 150 ppm NAA with a wetting agent or spreader-sticker, used according to the chemical manufacturer's recom- 
mendation. The commercially available NAA formulation Liqui-Stik Concentrate does not contain a wetting agent.

If you do use a spray oil, mix 100 ppm NAA with a light or light medium summer oil emulsion at a rate of $1 \frac{1}{2}$ gallons of oil per 100 gallons of spray mix. Do not use a wetting agent if you use oil.

The data in Table 1 show how to mix NAA LiquiStik Concentrate to produce specific concentrations.

CAUTION: Do not use oil with NAA when daytime temperatures are $90^{\circ} \mathrm{F}\left(32.2^{\circ} \mathrm{C}\right)$ or higher or when soil moisture is low. Failure to observe these precautions may result in leaf and shoot burn, defoliation, fruit injury, and excessive thinning.

\section{Varietal Responses Vary}

Manzanillo, Mission, and Ascolano varieties respond well to spray thinning. Sevillano olives do not respond well to this treatment.

\section{How Much Spray to Apply}

To be effective, the spray must cover the undersides of leaves on fruiting branches, but a heavy drenching application such as is used for scale control is usually unnecessary and wasteful. NOTE: No less than 108 ounces of NAA from Liqui-Stik Concentrate (NAA ammonium salt, 200 grams active ingredient [a.i.] per gallon) should be applied per acre (1239 grams a.i. per hectare). See Table 2 for the number of gallons per acre required to apply 108 ounces a.i. per acre at various concentrations.

\section{Equipment and How to Use It}

Air blast sprayers. When most trees bear a heavy crop, an air blast sprayer will do the best job of covering the whole tree. For good spray distribution, drive a properly adjusted air blast sprayer at 1.5 to 2 miles per hour.

High-pressure hand gun sprayers. Use high-pressure hand guns with number 8 discs at 200 to 400 pounds per square inch (psi) pressure if some trees in the orchard are overloaded and others are not. If only certain limbs in each tree require thinning, spot spraying may be effective. NOTE: Always leave some unsprayed check areas to help gauge the effectiveness of spray thinning.

\section{POTENTIAL FOR DAMAGE}

If used as directed and at moderate temperatures, NAA will not damage fruit or retard fruit growth. Sometimes
Table 1. Amount of NAA from Liqui-Stik Concentrate (NAA ammonium salt, $200 \mathrm{~g}$ a.i. per gallon) required per 100 gallons to make solutions of various concentrations

\begin{tabular}{lcc}
\hline $\begin{array}{l}\text { Desired } \\
\text { concentration of } \\
\text { NAA (ppm a.i.) }\end{array}$ & $\begin{array}{c}\text { Liqui-Stik } \\
\text { (fl. oz.) per } \\
\text { 100 gallons }\end{array}$ & $\begin{array}{c}\text { Liqui-Stik } \\
\text { (ml) per } \\
\text { 100 gallons }\end{array}$ \\
\hline 100 ppm & $24 \mathrm{fl.} \mathrm{oz}$. & $716 \mathrm{ml}$ \\
110 ppm & $26 \mathrm{fl} . \mathrm{oz}$. & $788 \mathrm{ml}$ \\
120 ppm & $29 \mathrm{fl.} \mathrm{oz}$. & $859 \mathrm{ml}$ \\
130 ppm & $31 \mathrm{fl.} \mathrm{oz}$. & $931 \mathrm{ml}$ \\
140 ppm & $34 \mathrm{fl.} \mathrm{oz}$. & $1002 \mathrm{ml}$ \\
150 ppm & $36 \mathrm{fl} . \mathrm{oz}$. & $1074 \mathrm{ml}$ \\
\hline
\end{tabular}

Table 2. Minimum gallons at various concentrations required to deliver $108 \mathrm{oz}$. of NAA from Liqui-Stik Concentrate (NAA ammonium salt, $200 \mathrm{~g}$ a.i. per gallon) per acre, with metric equivalents

\begin{tabular}{lcc}
\hline $\begin{array}{l}\text { NAA } \\
\text { concentration } \\
\text { (ppm a.i.) }\end{array}$ & $\begin{array}{l}\text { Gallons of } \\
\text { solution } \\
\text { required } \\
\text { per acre }\end{array}$ & $\begin{array}{l}\text { Liters of } \\
\text { solution } \\
\text { required } \\
\text { per hectare }\end{array}$ \\
\hline $100 \mathrm{ppm}$ & $450 \mathrm{gal} / \mathrm{A}$ & $4212 \mathrm{~L} / \mathrm{ha}$ \\
$110 \mathrm{ppm}$ & $415 \mathrm{gal} / \mathrm{A}$ & $3884 \mathrm{~L} / \mathrm{ha}$ \\
$120 \mathrm{ppm}$ & $372 \mathrm{gal} / \mathrm{A}$ & $3482 \mathrm{~L} / \mathrm{ha}$ \\
$130 \mathrm{ppm}$ & $348 \mathrm{gal} / \mathrm{A}$ & $3257 \mathrm{~L} / \mathrm{ha}$ \\
$140 \mathrm{ppm}$ & $317 \mathrm{gal} / \mathrm{A}$ & $2967 \mathrm{~L} / \mathrm{ha}$ \\
$150 \mathrm{ppm}$ & $300 \mathrm{gal} / \mathrm{A}$ & $2808 \mathrm{~L} / \mathrm{ha}$ \\
\hline
\end{tabular}

it does kill or curl young, tender tip growth on some new shoots, but this has no lasting effect.

\section{POINTS TO REMEMBER}

The effects of NAA depend upon dose, temperature at time of application, and tree condition.

Dose. The greater the applied concentration of NAA, the greater its thinning activity. You can further increase NAA activity by adding oils to the application mix.

Temperature. As temperatures rise, NAA activity increases. High temperatures (i.e., in excess of $100^{\circ} \mathrm{F}$ $\left[37.8^{\circ} \mathrm{C}\right]$ ) within two weeks after application can cause additional thinning.

Tree condition. Never spray water-stressed trees with NAA: it will cause excessive thinning. Trees to be sprayed with NAA must be well watered both as bloom develops and after spraying to mitigate any negative effects related to high temperatures. 


\section{FOR MORE INFORMATION}

You'll find detailed information on all aspects of olive production in Olive Production Manual, publication 3353.

To order a copy, or to request a catalog of UC DANR publications, slide sets, and videos, contact

University of California

Division of Agriculture and Natural Resources

Communication Services

6701 San Pablo Avenue, 2nd Floor

Oakland, California 94608-1239

Telephone: 1-800-994-8849 or (510) 642-2431

FAX: (510) 643-5470

e-mail inquiries:danrcs@ucdavis.edu

Visit us on the World Wide Web: http://danrcs.ucdavis.edu/

\section{WARNING ON THE USE OF CHEMICALS}

Pesticides are poisonous. Always read and carefully follow all precautions and safety recommendations given on the container label. Store all chemicals in their original labeled containers in a locked cabinet or shed, away from foods or feeds, and out of the reach of children, unauthorized persons, pets, and livestock.

Recommendations are based on the best information currently available, and treatments based on them should not leave residues exceeding the tolerance established for any particular chemical. Confine chemicals to the area being treated. THE GROWER IS LEGALLY RESPONSIBLE for residues on the grower's crops as well as for problems caused by drift from the grower's property to other properties or crops.

Consult your county agricultural commissioner for correct methods of disposing of leftover spray materials and empty containers. Never burn pesticide containers.

PHYTOTOXICITY: Certain chemicals may cause plant injury if used at the wrong stage of plant development or when temperatures are too high. Injury may also result from excessive amounts or the wrong formulation or from mixing incompatible materials. Inert ingredients, such as wetters, spreaders, emulsifiers, diluents, and solvents, can cause plant injury. Since formulations are often changed by manufacturers, it is possible that plant injury may occur, even though no injury was noted in previous seasons.

To simplify information, trade names of products have been used in this publication. No endorsement of named products is intended, nor is criticism implied of similar products that are not mentioned.

An electronic version of this publication is available via the UC DANR Communication Services Web Site at http://danrcs.ucdavis.edu/

Publication 7238

(C) 1998 by the Regents of the University of California, Division of Agriculture and Natural Resources.

All rights reserved.

The University of California, in accordance with applicable Federal and State law and University policy, does not discriminate on the basis of race, color, national origin, religion, sex, disability, age, medical condition (cancer-related), ancestry, marital status, citizenship, sexual orientation, or status as a Vietnam-era veteran or special disabled veteran. The University also prohibits sexual harassment. Inquiries regarding the University's nondiscrimination policies may be directed to the Affirmative Action Director, University of California, Agriculture and Natural Resources, 1111 Franklin Street, Oakland, CA 94607-5200; (510) 987-0096.

76-pr-9/98-WJC

ISBN 978-1-60107-029-6 